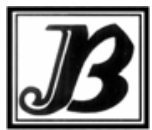

J. bio-sci. 20: 161-169, 2012

ISSN 1023-8654

http://www.banglajol.info/index.php/JBS/index

\title{
CALLUS INDUCTION AND CELL CULTURE OF CASTOR (RICINUS COMMUNIS L. CV. SHABJE)
}

\author{
M A Rahman and M A Bari * \\ Biotechnology Laboratory, Institute of Biological Sciences \\ University of Rajshahi, Rajshahi-6205, Bangladesh
}

\begin{abstract}
Context: Tissue culture is an important tool in plant biotechnology that allows for an increase in biomass or metabolite production by utilizing several techniques in callus or cell cultures. Ricin is a toxic protein that can be extracted from the castor bean as secondary metabolite. The ricin has been used experimentally in medicine to kill cancer cell. We developed callus and cell culture technique for the possible extraction of ricin from the cell suspension culture of Ricinus communis.

Objectives: The present investigation aimed to develop the cell culture technique of $R$. communis L. cv. Shabje and tried to establish a protocol for cell suspension culture of castor for possible extraction of ricin from cell extract.

Materials and Methods: The hypocotyl explants of $R$. communis L. CV. Shabje were used as experimental materials. Cultured on Murashige and Skoog medium supplemented with different concentrations and combinations of BAP, NAA, 2,4-D and IAA for callus induction. For cell culture, the media were used without agar with different concentrations and combinations of these hormones.

Results: For callus induction the combination of BAP $2.0 \mathrm{mg} / \mathrm{l}+0.5 \mathrm{mg} / \mathrm{l}$ NAA showed the best performance but in case of cell culture the combination of BAP $2.0 \mathrm{mg} / \mathrm{l}$ and $0.2 \mathrm{mg} / \mathrm{l} \mathrm{NAA}$ showed the best result.

Conclusion: The present investigation clearly established and demonstrated the method of obtaining cell suspension culture and important secondary metabolite ricin could be obtained from cell suspension culture of $R$. communis $L$. holding promises to explore cell culture industry for ricin production.
\end{abstract}

Key words: Castor, hypocotyl, embryogenic callus, cell culture and regeneration.

\section{Introduction}

On a global scale, medicinal plants are mainly used as crude drugs and extracts. Several of the more potent and active substances are employed as isolated compounds obtained from medicinal plants, including many alkaloids such as morphine (pain killer), codeine (antitussive), quinine papaverine (phosphordiesterase inhibitor), ephedrine (stimulant), ajmaline (antirrhythmic), (antimalarial), reserpine (antihypertensive), galanthamine (acetylecholine esterase inhibitor), scopolamine (travel sickness), berberine (psoriasis), caffeine (stimulant), capsaicin (rheumatic pains), colchicines (gout), yohimbine (aphrodisiac), pilocarpine (glaucoma), and various types of cardiac glycosides (heart insufficiency) (Wilken et al. 2005). Extraction from the in vitro tissues is much simpler than extraction from organized complex tissues of a plant. Cell cultures in this respect are very useful for the secondary metabolites they produce. Some of these metabolites that are valuable source include flavors, natural sweeteners, industrial feed stocks, perfumes and commercial

*Corresponding author Email: bari@ru.ac.bd 
insecticides. These products do not perform vital physiological functions like amino acids or nucleic acids, but they are produced to ward off potential predators, attract pollinators, or combat infectious diseases. Another useful metabolite produced by plants includes Shikokin, which is a chemical used as both a dye and a pharmaceutical. Plant cell suspension culture is valuable also for studying the biosynthesis of these secondary metabolites. Although there are limitations of cell culture systems in producing secondary metabolites, they are favored over conventional cultivation methods. This is because of their ability to produce useful compounds under controlled conditions as well as their capability of using this technique to produce chemicals to meet market demands.

Plant tissue and cell culture is an important tool in plant biotechnology that allows for an increase in biomass or metabolite production by utilizing several techniques in callus or morphogenetic cultures (Ramachandra and Ravishankar 2002, Dornenburg and Knorr 1995). Among others, these techniques include bioreactor scale-up, hairy transformed roots, micropropagation, elicitation, precursor compound addition and genetic engineering (Mulabagal and Tsay 2004, Smetanska 2008, Dornenburg and Knorr 1995). High in vitro multiplications have been reported for $R$. communis (Ahn et al. 2007) that produced ricin which is mostly known for its potential as a biological weapon. Castor oil is a triglyceride of fatty acids and almost 90 percent of its fatty acid content consists of ricinoleic acid. Ricinoleic acid is not found in any other substance except castor oil (Willams 1995). Ricin has been used experimentally in medicine to kill cancer cell. Ricin is a secondary metabolite toxic protein abundantly produced from castor bean and it can also be obtained from callus and cell culture of $R$. communis. As Calophyllum brasiliense (Cambes) produces calanolide secondary metabolites that are active against human immunodeficiency virus type 1 reverse transcriptase which was isolated by callus culture (Bernabé-Antonio et al. 2010). Acridone and furoquinoline alkaloids and coumarins have been isolated from four week old calli in Ruta species (Alfred Baumert 1992). The production of the steroidal sapogenin and diosgenin by callus cultures of Trigonella foenum-graecum L. (Fenugreek) was reported by Oncina et al. in 2000. In addition, plant cell culture also offers an attractive alternative source to whole plant for the production of high-value secondary metabolites (Ravishankar et al. 1999, Dornenburg and Knorr 1995, Scragg 1997, Alfermann and Petersen 1995, DiCosmo and Misawa 1995, Stockigt et al. 1995, Ravishankar and Venkataraman 1990). Plant cell culture systems represent a potential renewable source of valuable medicinal, flavors, essences and colorants that cannot be produced by microbial cells or chemical syntheses. However, only a few cultures produce these compounds in commercially useful amounts. The low productivities are associated with our poor understanding of the biochemistry of these systems. Recent advances in molecular biology, enzymology, physiology and fermentation technology of plant cell cultures suggest that these systems will become a viable source of important natural products.

In Bangladesh $R$. communis is widely grown all over the country holding great potential for producing castor oil as a source of green energy and also for commercial production of toxic protein ricin. We have developed the standard protocol for in vitro regeneration of $R$. communis and under the present investigation we have made efforts to develop the standard protocol for wide scale callus culture and cell culture of $R$. communis towards isolation of active protein ricin from these cultures.

\section{Materials and Methods}

The hypocotyl explants of $R$. communis L. cv. Shabje, were used as experimental materials in the present investigation. Seeds were collected from the research field of the Institute of Biological Sciences, Rajshahi University, Rajshahi, Bangladesh. Seeds were washed thoroughly under running tap water and then treated 
with 1\% Savlon and 2-3 drops of Tween-80 for about 10 min. This was followed by successive three washing with distilled water to make free the seeds from Savlon and Tween-80. Surface sterilization was carried out with $0.1 \% \mathrm{HgCl}_{2}$ for 6-7 min followed by gentle shaking. After this treatment, the seeds were rinsed 4-5 times in sterile distilled water to make free the seeds from $\mathrm{HgCl}_{2}$. Sterilized seeds were partially decorticated and aseptically germinated in glass bottle containing $50 \mathrm{ml}$ of autoclaved $\left(121^{\circ} \mathrm{C}\right.$ temperature for 20 minutes at $1.1 \mathrm{Kg} / \mathrm{cm}^{2}$ pressure) MS (Murashige and Skoog 1962) medium, fortified with BAP (1.0 mg/l), $30 \mathrm{gm} / \mathrm{l}$ sucrose and $0.8 \mathrm{gm} / \mathrm{l}$ agar.

Callus culture: Hypocotyl segments as explants were taken from 8 days old in vitro grown seedlings of the plant. The explants were cultured in $9 \mathrm{~cm}$ petri dish and placed horizontally on the callus induction medium. The MS medium supplemented with $3 \%$ sucrose and different concentrations of NAA, 2, 4-D, IAA and BAP in combination were compared for the induction of callus. The data for callus initiation were scored after 4 weeks of culture.

Cell culture: Rapidly proliferating friable calli subcultured for 18 days, were aseptically transferred to MS liquid medium supplemented with $2.0 \mathrm{mg} / \mathrm{BAP}+0.05 \mathrm{mg} / \mathrm{lNAA}, 2.0 \mathrm{mg} / \mathrm{l} \mathrm{BAP}+0.2 \mathrm{mg} / \mathrm{lNAA}$ and $2.0 \mathrm{mg} / \mathrm{l}$ $\mathrm{BAP}+0.5 \mathrm{mg} / \mathrm{l} \mathrm{NAA}$ in three lots in $250 \mathrm{ml}$ flasks. The flasks were placed on a rotary shaker $(100 \mathrm{rpm})$. After 4 days, the liquid medium containing cells and micro calli were filtered through a 500 micron mesh sieve. The filtrates containing cell were maintained in the laboratory. To observe the growth efficiency, flasks containing the liquid medium with cell culture were kept in an orbital shaker. Cell growth was measured by weighting the cells in $5 \mathrm{ml}$ liquid medium taken after every two days. On the other hand, to obtain callus, some cells were distributed to petri dishes $(4 \mathrm{~cm})$ containing the fresh semi solid medium at $25^{\circ} \mathrm{C}$ in dark for $35-42$ days of incubation. Micro calli were appeared in the plates initiating induction of callus from cell aggregates.

\section{Results}

Callus induction: The surface sterilized seeds exhibited 95\% germination after 10 days of inoculation on MS medium supplemented with $1.0 \mathrm{mg} / \mathrm{BAP}$. For callus induction, hypocotyl explants were taken from in vitro grown seedlings and cultured on MS media supplemented with cytokinin (BAP $0.5 \mathrm{mg} / \mathrm{l}-3.0 \mathrm{mg} / \mathrm{l}$ ) in combination with auxins (NAA $0.1 \mathrm{mg} / \mathrm{l}-1.0 \mathrm{mg} / \mathrm{l}, 2,4-\mathrm{D} 0.1 \mathrm{mg} / \mathrm{l}-1.0 \mathrm{mg} / \mathrm{l}$ and IAA $0.1 \mathrm{mg} / \mathrm{l}-1.0 \mathrm{mg} / \mathrm{l}$ ). Different concentrations took different time periods for callus induction. Data on response after inoculation, percentage of explants responded and natures of callus were recorded and the results are presented in Table 1. When the explants were cultured on MS media containing different combinations and concentrations of BAP $(0.5 \mathrm{mg} / \mathrm{l}-3.0 \mathrm{mg} / \mathrm{l})$ and NAA $(0.1 \mathrm{mg} / \mathrm{l}-1.0 \mathrm{mg} / \mathrm{l})$ highest rate $100 \%$ callus induction was obtained in both the combinations of $2.0 \mathrm{mg} / \mathrm{BAP}+0.5 \mathrm{mg} / \mathrm{lNAA}$ and $2.0 \mathrm{mg} / \mathrm{l} \mathrm{BAP}+0.8 \mathrm{mg} / \mathrm{l} \mathrm{NAA}$. The induced calli were green in color, compact and nodular (Fig. $1 \mathrm{~B}$ ). When the explants were cultured on MS media containing different combinations and concentrations of BAP $(0.5 \mathrm{mg} / \mathrm{l}-3.0 \mathrm{mg} / \mathrm{l})$ with 2 , 4-D $(0.1 \mathrm{mg} / \mathrm{l}-1.0$ $\mathrm{mg} / \mathrm{ll}$ ) highest rate $91.5 \%$ callus induction was obtained in $2.0 \mathrm{mg} / \mathrm{lBAP}+0.8 \mathrm{mg} / \mathrm{l} 2,4-\mathrm{D}$ and the induced calli were green in color and compact in structure ( Fig. 1.C). When the explants were cultured on MS medium containing different combinations and concentrations of BAP $(0.5 \mathrm{mg} / \mathrm{l}-3.0 \mathrm{mg} / \mathrm{l})$ with IAA $(0.1 \mathrm{mg} / \mathrm{l}-1.0$ $\mathrm{mg} / \mathrm{l})$ highest rate $54.5 \%$ was obtained in $2.0 \mathrm{mg} / \mathrm{BAP}+0.5 \mathrm{mg} / \mathrm{IAA}$ and the induced calli were green and compact (Fig. 1. D). The experiments in our investigation also demonstrated that combined effect of BAP and NAA showed the best performance in callus induction in $R$. communis $L$. On the other hand, the embryogenic calli were green and compact while the non embryogenic calli were large, white and friable. 
Table 1. Effect of different growth regulators on callus induction of Ricinus communis $L \mathrm{cv}$ Shabje from hypocotyl explant (Each treatment consisted of 20 explants).

\begin{tabular}{|c|c|c|c|c|c|c|c|c|c|c|c|}
\hline \multicolumn{4}{|c|}{$\begin{array}{l}\text { Effect of different concentrations and } \\
\text { combinations of BAP and NAA in MS } \\
\text { medium on callus induction }\end{array}$} & \multicolumn{4}{|c|}{$\begin{array}{l}\text { Effect of different concentrations and } \\
\text { combinations of BAP and 2,4-D in MS } \\
\text { medium on callus induction }\end{array}$} & \multicolumn{4}{|c|}{$\begin{array}{l}\text { Effect of different concentrations and } \\
\text { combinations of BAP and IAA in MS } \\
\text { medium on callus induction }\end{array}$} \\
\hline $\begin{array}{l}\text { Conc. of } \\
\text { growth } \\
\text { regulator } \\
\mathrm{s}(\mathrm{mg} / \mathrm{l})\end{array}$ & \multirow[t]{3}{*}{$\begin{array}{l}\text { Res- } \\
\text { ponse } \\
\text { after } \\
\text { days }\end{array}$} & \multirow[t]{3}{*}{$\begin{array}{l}\% \text { of } \\
\text { explants } \\
\text { respond } \\
\text { ed }\end{array}$} & \multirow[t]{3}{*}{$\begin{array}{l}\text { Nature } \\
\text { of callus }\end{array}$} & $\begin{array}{l}\text { Conc. of } \\
\text { growth } \\
\text { regulator } \\
\mathrm{s}(\mathrm{mg} / \mathrm{l})\end{array}$ & \multirow[t]{3}{*}{$\begin{array}{l}\text { Res- } \\
\text { ponse } \\
\text { after } \\
\text { days }\end{array}$} & \multirow[t]{3}{*}{$\begin{array}{l}\text { Res- } \\
\text { ponse } \\
\text { after } \\
\text { days }\end{array}$} & \multirow[t]{3}{*}{$\begin{array}{l}\text { Nature of } \\
\text { callus }\end{array}$} & $\begin{array}{l}\text { Conc. of } \\
\text { growth } \\
\text { regulators } \\
\text { (mg/l) }\end{array}$ & \multirow[t]{3}{*}{$\begin{array}{l}\text { Res- } \\
\text { ponse } \\
\text { after } \\
\text { days }\end{array}$} & \multirow[t]{3}{*}{$\begin{array}{l}\text { Res- } \\
\text { ponse } \\
\text { after } \\
\text { days }\end{array}$} & \multirow[t]{3}{*}{$\begin{array}{l}\text { Nature } \\
\text { of } \\
\text { callus }\end{array}$} \\
\hline BAP+ & & & & BAP+ & & & & BAP+ & & & \\
\hline NAA & & & & 2,4-D & & & & IAA & & & \\
\hline $0.5+0.1$ & 13 & 18.5 & WG & $0.5+0.1$ & 14 & 8.2 & WG & $0.5+0.1$ & 15 & 8.9 & WG \\
\hline $0.5+0.2$ & 9 & 37.4 & GF & $0.5+0.2$ & 11 & 20.1 & WG & $0.5+0.2$ & 14 & 10.1 & WG \\
\hline $0.5+0.5$ & 8 & 44.6 & GF & $0.5+0.5$ & 10 & 36.3 & GF & $0.5+0.5$ & 13 & 21.0 & GF \\
\hline \multirow{2}{*}{$\begin{array}{l}0.5+0.80 \\
.5+1.0\end{array}$} & 7 & 52.4 & GF & $0.5+0.8$ & 9 & 42.2 & GF & $0.5+0.8$ & 12 & 23.2 & GF \\
\hline & 7 & 28.7 & GF & $0.5+1.0$ & 9 & 39.7 & GF & $0.5+1.0$ & 12 & 25.3 & GF \\
\hline $1.0+0.1$ & 12 & 22.8 & WG & $1.0+0.1$ & 13 & 10.3 & WG & $1.0+0.1$ & 14 & 12.1 & WG \\
\hline $1.0+0.2$ & 8 & 47.5 & GF & $1.0+0.2$ & 10 & 28.3 & WG & $1.0+0.2$ & 13 & 22.0 & WG \\
\hline $1.0+0.5$ & 7 & 63.6 & GF & $1.0+0.5$ & 9 & 46.5 & GF & $1.0+0.5$ & 12 & 28.5 & GF \\
\hline $1.0+0.8$ & 6 & 78.5 & GC & $1.0+0.8$ & 8 & 66.2 & GF & $1.0+0.8$ & 11 & 34.2 & GF \\
\hline $1.0+1.0$ & 6 & 51.3 & GC & $1.0+1.0$ & 8 & 59.1 & GF & $1.0+1.0$ & 11 & 38.5 & GF \\
\hline $1.5+0.1$ & 11 & 29.1 & WG & $1.5+0.1$ & 12 & 14.5 & WG & $1.5+0.1$ & 13 & 14.5 & WG \\
\hline $1.5+0.2$ & 7 & 55.2 & GF & $1.5+0.2$ & 9 & 36.0 & WG & $1.5+0.2$ & 12 & 32.1 & WG \\
\hline $1.5+0.5$ & 6 & 81.1 & GF & $1.5+0.5$ & 8 & 57.3 & GF & $1.5+0.5$ & 11 & 43.2 & GF \\
\hline $1.5+0.8$ & 5 & 91.0 & GC & $1.5+0.8$ & 7 & 73.1 & GC & $1.5+0.8$ & 10 & 47.2 & GC \\
\hline $1.5+1.0$ & 5 & 60.2 & GC & $1.5+1.0$ & 7 & 65.8 & GC & $1.5+1.0$ & 10 & 45.1 & GC \\
\hline $2.0+0.1$ & 10 & 31.9 & WG & $2.0+0.1$ & 11 & 15.9 & GF & $2.0+0.1$ & 12 & 16.2 & WG \\
\hline $2.0+0.2$ & 6 & 85.5 & GF & $2.0+0.2$ & 8 & 41.3 & GF & $2.0+0.2$ & 11 & 41.0 & GF \\
\hline $2.0+0.5$ & 5 & 100.0 & $\mathrm{GCN}$ & $2.0+0.5$ & 7 & 71.2 & GC & $2.0+0.5$ & 10 & 54.5 & GC \\
\hline $2.0+0.8$ & 4 & 100.0 & $\mathrm{GCN}$ & $2.0+0.8$ & 6 & 91.5 & GC & $2.0+0.8$ & 9 & 53.4 & GC \\
\hline $2.0+1.0$ & 4 & 77.3 & GCN & $2.0+1.0$ & 6 & 82.6 & GC & $2.0+1.0$ & 9 & 52.3 & GC \\
\hline $2.5+0.1$ & 11 & 30.2 & WG & $2.5+0.1$ & 12 & 14.1 & GF & $2.5+0.1$ & 13 & 16.5 & WG \\
\hline $2.5+0.2$ & 7 & 58.1 & GF & $2.5+0.2$ & 9 & 45.2 & GF & $2.5+0.2$ & 12 & 36.3 & GF \\
\hline $2.5+0.5$ & 6 & 81.3 & GC & $2.5+0.5$ & 8 & 61.0 & GC & $2.5+0.5$ & 11 & 50.2 & GC \\
\hline $2.5+0.8$ & 5 & 89.1 & GC & $2.5+0.8$ & 7 & 80.4 & GC & $2.5+0.8$ & 10 & 51.5 & GC \\
\hline $2.5+1.0$ & 5 & 62.0 & GC & $2.5+1.0$ & 7 & 72.6 & GC & $2.5+1.0$ & 10 & 50.4 & GC \\
\hline $3.0+0.1$ & 11 & 20.9 & WG & $3.0+0.1$ & 12 & 15.0 & GF & $3.0+0.1$ & 13 & 15.1 & WG \\
\hline $3.0+0.2$ & 8 & 37.2 & GF & $3.0+0.2$ & 9 & 41.6 & GF & $3.0+0.2$ & 12 & 30.1 & GF \\
\hline $3.0+0.5$ & 7 & 63.2 & GC & $3.0+0.5$ & 8 & 52.2 & GF & $3.0+0.5$ & 11 & 39.2 & GF \\
\hline $3.0+0.8$ & 6 & 72.0 & GC & $3.0+0.8$ & 7 & 68.5 & GF & $3.0+0.8$ & 10 & 38.0 & GF \\
\hline $3.0+1.0$ & 6 & 55.7 & GF & $3.0+1.0$ & 7 & 56.3 & GF & $3.0+1.0$ & 10 & 35.1 & GF \\
\hline \multicolumn{4}{|c|}{$\begin{array}{l}\text { WG - whitish green, GF - green friable, GC - } \\
\text { green compact, GCN - green compact } \\
\text { nodular. }\end{array}$} & \multicolumn{4}{|c|}{$\begin{array}{l}\text { WG - whitish green, GF - green friable, GC - } \\
\text { green compact. }\end{array}$} & \multicolumn{4}{|c|}{$\begin{array}{l}\text { WG - whitish green, GF - green friable, GC - } \\
\text { green compact. }\end{array}$} \\
\hline
\end{tabular}




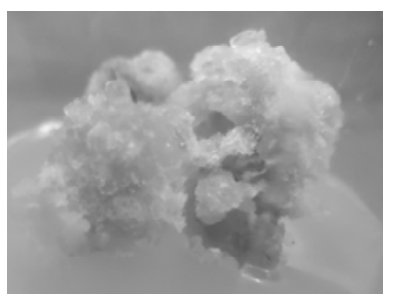

A

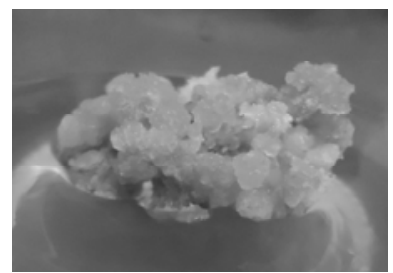

C

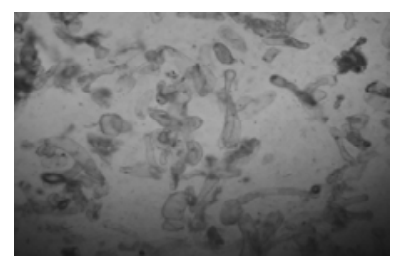

$E$

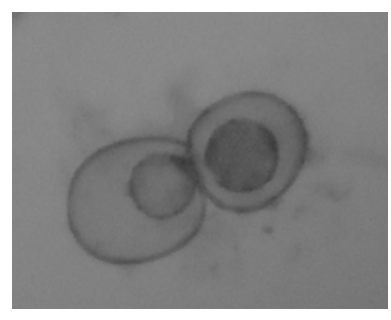

G

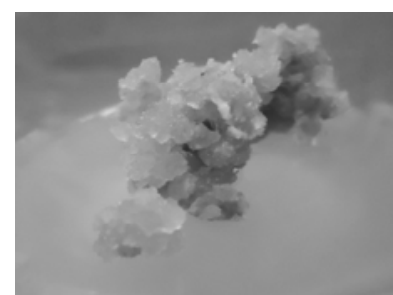

B

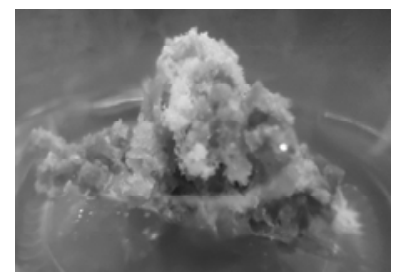

D

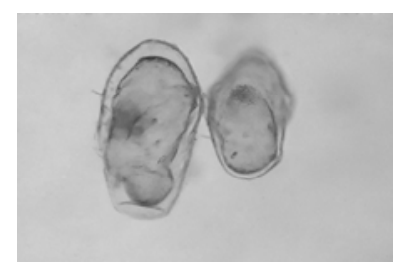

$\mathbf{F}$

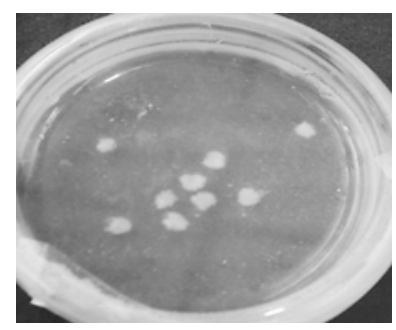

H

Fig. 1. A. Three weeks old whitish green callus. B. Four weeks old green compact nodular organic callus. C. Five weeks old green compact callus. D. Six weeks old green compact callus. E. Isolated cells. F. Isolated single cells. G. Cell division. H. Callus induction from single cells.

\section{Cell culture:}

Rapidly proliferating greenish friable embryonic calli (about 1-2 gm fresh weight) grown in solid medium were considered as the better candidate for initiation of cell suspension culture in castor. Embryonic calli in solid media containing $2.0 \mathrm{mg} / \mathrm{l} \mathrm{BAP}+0.5 \mathrm{mg} / \mathrm{l} \mathrm{NAA}$ were used to initiate cell suspension in liquid medium. Cell culture experiment was started in three separate lots in three $250 \mathrm{ml}$ flasks in liquid MS medium contain 2.0 
$\mathrm{mg} / \mathrm{BAP}+0.05 \mathrm{mg} / \mathrm{l} \mathrm{NAA}, 2.0 \mathrm{mg} / \mathrm{lBAP}+0.2 \mathrm{mg} / \mathrm{l} \mathrm{NAA}$ and $2.0 \mathrm{mg} / \mathrm{l} \mathrm{BAP}+0.5 \mathrm{mg} / \mathrm{l} \mathrm{NAA}$. The flasks were placed on a rotary shaker $(100 \mathrm{rpm})$ in dark and within 4 days cells in the liquid medium appeared distinctly visible and under microscope they were found in different growth stages (Fig.1. E, F and G). Cell weight was recorded nine times with every 2 days intervals. The summarized results are shown in the Table 2. Cells were found to grow continuously in three flasks with three media combinations of BAP and NAA. But when the cells were cultured on the MS medium having $2.0 \mathrm{mg} / \mathrm{BAP}+0.2 \mathrm{mg} / \mathrm{NAA}$, the rate of cell growth found the highest than that of MS medium having $2.0 \mathrm{mg} / \mathrm{lBAP}+0.05 \mathrm{mg} / \mathrm{lNAA}$ and $2.0 \mathrm{mg} / \mathrm{l} \mathrm{BAP}+0.5 \mathrm{mg} / \mathrm{l} \mathrm{NAA}$ but in all cases, the cells continued to grow until 14 days. The peak period of cell growth was observed from $4^{\text {th }}$ day to $6^{\text {th }}$ day.

The mean value of three combinations were calculated and plotted in a graph and presented in Fig. 2 The results presented in the graph indicated that three media combinations showed the similar trend of cell growth and their growths were found highest in between 4-6 days. After 10 days their growth found to be stationary in the artificial medium and under given environmental condition of the laboratory.

Table 2. Cell weight of $R$. communis L. Cv. Shabuje growing after different periods.

\begin{tabular}{|c|c|c|c|c|c|c|c|c|c|c|c|c|}
\hline \multirow{3}{*}{ Times } & \multicolumn{12}{|c|}{ Combination of growth regulators } \\
\hline & \multicolumn{4}{|c|}{$2.0 \mathrm{mg} / \mathrm{l} \quad \mathrm{BAP}+0.05 \mathrm{mg} / \mathrm{l} \mathrm{NAA}$} & \multicolumn{4}{|c|}{$2.0 \mathrm{mg} / \mathrm{l} \quad \mathrm{BAP}+0.2 \mathrm{mg} / \mathrm{l} \mathrm{NAA}$} & \multicolumn{4}{|c|}{$2.0 \mathrm{mg} / / \mathrm{BAP}+0.5 \mathrm{mg} / \mathrm{l} \mathrm{NAA}$} \\
\hline & $\begin{array}{l}\text { Fla.1 } \\
(\mathrm{mg} /)\end{array}$ & $\begin{array}{l}\text { Fla.2 } \\
(\mathrm{mg} /)\end{array}$ & $\begin{array}{l}\text { Fla.3 } \\
\text { (mg/) }\end{array}$ & $\begin{array}{l}\text { Mean } \\
\text { (gm) }\end{array}$ & $\begin{array}{l}\text { Fla.1 } \\
(\mathrm{mg} /)\end{array}$ & $\begin{array}{l}\text { Fla.2 } \\
(\mathrm{mg} /)\end{array}$ & $\begin{array}{l}\text { Fla.3 } \\
\text { (mg/) }\end{array}$ & $\begin{array}{l}\text { Mean } \\
\text { (gm) }\end{array}$ & $\begin{array}{l}\text { Fla.1 } \\
(\mathrm{mg} /)\end{array}$ & $\begin{array}{l}\text { Fla.2 } \\
(\mathrm{mg} /)\end{array}$ & $\begin{array}{l}\text { Fla.3 } \\
(\mathrm{mg} /)\end{array}$ & $\begin{array}{l}\text { Mean } \\
\text { (gm) }\end{array}$ \\
\hline $\begin{array}{l}\text { After } \\
2 \text { days }\end{array}$ & 0.056 & 0.084 & 0.079 & 0.073 & 0.089 & 0.074 & 0.098 & 0.087 & 0.067 & 0.089 & 0.075 & 0.077 \\
\hline $\begin{array}{l}\text { After } \\
4 \text { days }\end{array}$ & 0.068 & 0.097 & 0.093 & 0.086 & 0.103 & 0.092 & 0.111 & 0.102 & 0.072 & 0.096 & 0.081 & 0.083 \\
\hline $\begin{array}{l}\text { After } \\
6 \text { days }\end{array}$ & 0.092 & 0.118 & 0.114 & 0.108 & 0.125 & 0.118 & 0.123 & 0.122 & 0.086 & 0.114 & 0.097 & 0.099 \\
\hline $\begin{array}{l}\text { After } \\
8 \text { days }\end{array}$ & 0.104 & 0.126 & 0.124 & 0.118 & 0.133 & 0.126 & 0.131 & 0.130 & 0.098 & 0.122 & 0.107 & 0.109 \\
\hline $\begin{array}{l}\text { After } \\
10 \text { days }\end{array}$ & 0.110 & 0.130 & 0.129 & 0.123 & 0.139 & 0.132 & 0.137 & 0.136 & 0.103 & 0.125 & 0.111 & 0.113 \\
\hline $\begin{array}{l}\text { After } \\
12 \text { days }\end{array}$ & 0.115 & 0.134 & 0.132 & 0.127 & 0.144 & 0.135 & 0.141 & 0.140 & 0.106 & 0.126 & 0.113 & 0.115 \\
\hline $\begin{array}{l}\text { After } \\
14 \text { days }\end{array}$ & 0.117 & 0.135 & 0.134 & 0.129 & 0.149 & 0.135 & 0.145 & 0.143 & 0.108 & 0.126 & 0.114 & 0.116 \\
\hline $\begin{array}{l}\text { After } \\
16 \text { days }\end{array}$ & 0.117 & 0.135 & 0.134 & 0.129 & 0.150 & 0.135 & 0.145 & 0.143 & 0.108 & 0.126 & 0.114 & 0.116 \\
\hline $\begin{array}{l}\text { After } \\
18 \text { days }\end{array}$ & 0.116 & 0.133 & 0.132 & 0.127 & 0.145 & 0.134 & 0.141 & 0.140 & 0.108 & 0.124 & 0.113 & 0.115 \\
\hline
\end{tabular}




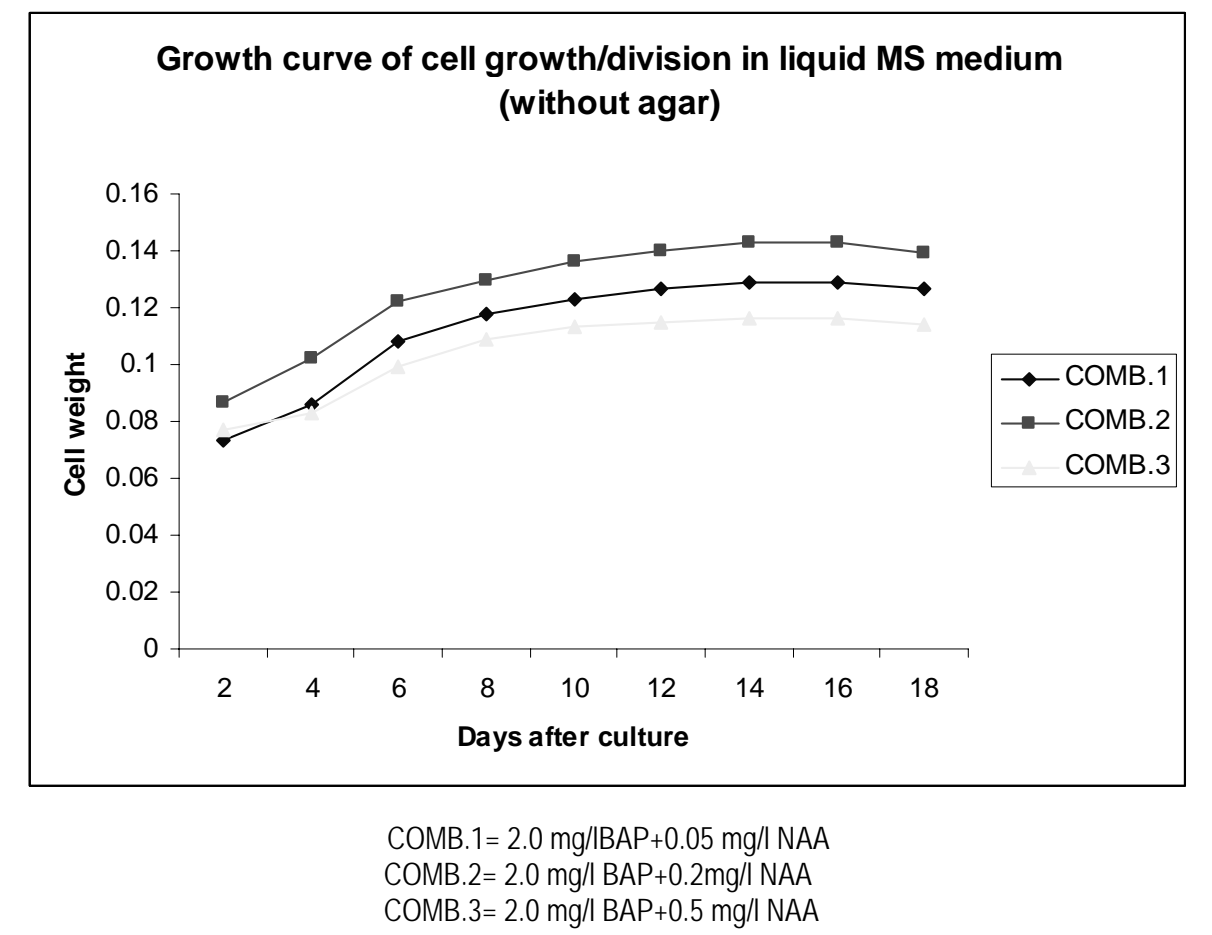

Fig. 2. Growth curve of cell growth / division in liquid MS medium.

\section{Discussion}

Under the present investigation in castor, embryogenic calli were induced when explants were cultured on MS medium containing auxin with cytokinin (BAP). The explant showed highest percentage (100\%) of embryogenic callus when NAA was used with BAP in MS medium supplemented with $2.0 \mathrm{mg} / \mathrm{l}$ BAP +0.5 $\mathrm{mg} / \mathrm{NAA}$ and $2.0 \mathrm{mg} / \mathrm{BAP}+0.8 \mathrm{mg} / \mathrm{NAA}$. Similar results were reported by Kumari et al. (2008) in $R$. communis $\mathrm{L}$. and they obtained callus induction from cotyledon explants using combination of BAP $2.0 \mathrm{mg} / \mathrm{l}$ and $0.8 \mathrm{mg} / \mathrm{l} \mathrm{NAA}$. Vila et al. (2003) also reported similar results in Melia azedarach, they obtained callus cultures using combination of BA $(4.4 \mu \mathrm{M})$ and NAA $(0.46 \mu \mathrm{M})$.

The embryogenic calli were then placed on a shaker to allow the cell aggregates to disperse to form smaller clumps of single cells equally distributed throughout the liquid media. The cells were found continuously growing until one of the factors became limiting causing cell growth to slow. Better performance of the isolated cells depends on the condition of embryogenic calli from which they were derived and the duration of their subculture. Under the present investigation in castor, cells were cultured on the MS media having 2.0 $\mathrm{mg} / \mathrm{BAP}+0.2 \mathrm{mg} / \mathrm{l} \mathrm{NAA}$, the rate of cell growth found highest than that of MS media having $2.0 \mathrm{mg} / \mathrm{l} \mathrm{BAP}+$ $0.05 \mathrm{mg} / \mathrm{l} \mathrm{NAA}$ and $2.0 \mathrm{mg} / \mathrm{l} \mathrm{BAP}+0.5 \mathrm{mg} / \mathrm{NAA}$. But in all cases, the cell continued to grow until 14 days. The peak period of cell growth was observed from $4^{\text {th }}$ day to $6^{\text {th }}$ day. Similar result was obtained in brinjal and cell growth highest peak within 4-6 days of incubation (Hossain et al. 2007) was noticed. Similar peak period of cell growth was obtained in Abrus precatorius where cells attained their highest peak within $6-8$ days of growth (Bari et al. 2009). Similar results were also reported in sugar beets, using different concentrations and 
combinations of BAP and 2,4-D, the growth patterns of cell suspension cultures were examined during a range of culture periods $(0,3,5,7,9,11,13$ and 15 days). In all lines, the growth rates of cells were initially slow but as the culture proceeded, they increased significantly and accumulated great amounts of biomass over a period of 15 days in Sugar Beet (Songül et al. 2002). The time required to establish the cell suspension culture varies greatly and depends on the tissue of the plant species and the medium composition. The use of fine suspension culture offers the opportunity to confirm single cell origin of somatic embryos and the asymmetry of the first cell division, which starts the process.

From the foregoing discussion it may be concluded that the auxins NAA, 2,4-D and IAA have role in callus induction but $2.0 \mathrm{mg} / \mathrm{l} \mathrm{BAP}+0.5 \mathrm{mg} / \mathrm{l} \mathrm{NAA}$ and $2.0 \mathrm{mg} / \mathrm{l} \mathrm{BAP}+0.8 \mathrm{mg} / \mathrm{l} \mathrm{NAA}$ concentrations proved to be most suitable combinations for induction of embryonic calli of $R$. communis. Under this investigation NAA in combination with BAP proved to be suitable media composition for enhancing cell growth of $R$. communis in artificial medium. The present experiments clearly demonstrated that in $R$. communis, cell begins to grow only within 4 days of culture proving its potential for developing cell culture industry for production of important toxic protein ricin as secondary metabolite. In regards of other medicinal plants $R$. communis proved suitable plant species for developing cell suspension culture in artificial medium and the present findings open up a new potential venture for obtaining secondary metabolites ricin as a alternative source from its cell .

\section{Acknowledgement}

The authors are thankful to HEQEP, Ministry of Education, Govt. of the People's Republic of Bangladesh for providing research grant for strengthening research facilities in the Biotechnology Lab, Institute of Biological Sciences, Rajshahi University, Bangladesh which has made enable to pursue this advance research work.

\section{References}

Ahn YJ, Vang L, McKeon TA, Chen GQ. 2007. High-frequency plant regeneration through adventitious shoot formation in castor (Ricinus communis L.). In Vitro Cell Dev Biol-Plant 43, 9-15. http://dx.doi.org/10.1007/s11627-006-9009-2

Alfermann AW, Petersen M. 1995. Natural products formation by plant cell biotechnology. Plant Cell Tissue Org Cult 43,199-205.

Alfred Baumert, Detlef Groger, Inna N. Kuzovkina Johannes Reisch. 1992. Secondary metabolites produced by callus cultures of various Ruta species. Plant Cell Tissue and Organ Culture. 28,159-162. http://dx.doi.org/10.1007/BF00055511

Bari MA, Banu LA, Hossain MJ. 2009. Cell suspension culture and somatic embryogenesis in Abrus precatorius. Intl J Bio Res 7 (4), 19-24.

Bernabé-Antonio A, Estrada-Zuniga ME, Buendia L-Gonzalez, Reyes R-Chilpa, Chavez VM-Avila, Cruz F-Sosa. 2010. Production of anti-HIV-1 calanolides in a callus culture of Calophyllum brasiliense (Cambes).Journal of Plant Biotechnology 103( 1), 33-40.

DiCosmo F, Misawa M. 1995.Plant cell and tissue culture: alternatives for metabolite production. Biotechnol Adv 13, 42535. http://dx.doi.org/10.1016/0734-9750(95)02005-N

Dornenburg H, Knorr D.1995. Strategies for the improvement of secondary metabolite production in plant cell cultures. Enzyme Microb Tech 17, 674-684. http://dx.doi.org/10.1016/0141-0229(94)00108-4

Hossain MJ, Rahman M, Bari MA. 2007. Establishment of Cell Suspension Culture and Plantlet Regeneration of Brinjal (Solanum melongena L.). Journal of Plant Sciences 2(4), 407-415. http://dx.doi.org/10.3923/ips.2007.407.415 
Jamal M, Bari MA. 2011. Shoot tip culture, somatic embryogenesis and cell suspension culture in banana [Unpublished Ph.D. Thesis]. Institute of Biological Sciences. University of Rajshahi, Bangladesh.

Kumari KG, Ganesan M, Jayabalan N. 2008. Somatic organogenesis and plant regeneration in Ricinus communis. Biol Plantarum 52, 17-25. http://dx.doi.org/10.1007/s10535-008-0003-x

Mulabagal V, Tsay HS. 2004. Plant cell cultures - an alternative and efficient source for the production of biologically important secondary metabolites. Int J Appl Sci Eng 2, 29-48.

Murashige T, Skoog F.1962. A revised medium for rapid growth and bioassay with tobacco tissue culture. Plant physiol 15, 473-497. http://dx.doi.org/10.1111/.1399-3054.1962.tb08052.x

Oncina R, Bota JM, del RoJA, Ortuno A . 2000. Bio-production of diosgenin in callus cultures of Trigonella toenumgraecum L. Food Chemistry 70, 489-492. http://dx.doi.org/10.1016/S0308-8146(00)00121-7

Ramachandra RS, Ravishankar GA .2002. Plant cell culture: chemical factories of secondary metabolites. Biotechnol Adv 20, 101-153. http://dx.doi.org/10.1016/S0734-9750(02)00007-1

Ravishankar GA, Bhyalakshmi N, Ramachandra Rao S. 1999. Production of food additives. In: Ramawat KG, Merillon JM eds. Biotechnology: Secondary metabolites .Oxford IBH. 89-110 pp.

Ravishankar GA, Venkataraman LV.1990. Food applications of plant cell cultures. Curr Sci 59 (9), 14-20.

Scragg AH.1997. The production of aromas by plant cell cultures. In: Schepier T, editor. Adv Biochem Eng Biotechnol, vol. 55. Berlin: Springer-Verlag, 1997. pp. 239-63. New Delhi: Oxford IBH, 89-110 pp.

Smetanska I. 2008. Production of secondary metabolites using plant cell cultures. Adv Biochem Eng Biotechnol 111, 187-228. http://dx.doi.org/10.1007/10 2008103

Songül GŪREL, Ekrem GŪREL, Zeki KAYA. 2002. Establishment of Cell Suspension Cultures and Plant Regeneration in Sugar Beet (Beta vulgaris L.). Turk J Bot 26, 197-205).

Stockigt J, Obitz P, Flakenhagen H, Lutterbach R, Endress R. 1995. Natural products and enzymes from plant cell cultures. Plant Cell Tissue Org Cult 43, 914-20. http://dx.doi.org/10.1007/BF00052163

Vila SK, Gonzalez AM, Rey HY, Mroginski LA. 2003. In vitro plant regeneration of Melia azedarach L. Shoot organogenesis from leaf explants. Biol Plant 47, 13-19. http://dx.doi.org/10.1023/A:1027364427795

Wilken D, Gonzales EJ, Hohe A, Jordan M, Kosky RG, Hirschmann GS, Gerth A. 2005. Comparison of secondary plant metabolite production in cell suspension, callus culture and temporary immersion system. Liquid Culture Systems for in vitro Plant Propagation, A.K. Hvoslef-Eide and W. Preil (eds.) Chapter 39, Springer, 525-537 pp.

Williams David G. 1995. Castor Oil- Natural protection from Deadly Viruses. Electroherbalism. Vol 6 No.1. Available at:: http://www.electroherbalism.com/Naturopathy/Therapies/Diet/FatsandOils/CastorOil.htm. 